\title{
PELUANG DAN TANTANGAN E-COMMERCE DALAM DUNIA PERBANKAN DAN OTONOMI DAERAH
}

\author{
Darnilawati \\ Fakultas Syariah dan Ilmu Hukum UIN Suska Riau \\ dwati2009@gmail.com
}

\begin{abstract}
The development of E-commerce as a medium of trade is supported by many of today's world economy demands that emphasizes on the aspects of globalization, liberalization, and development of technology and telecommunications to fulfill the needs of trade and consumers. E-commerce changes the operating of trade, especially in the banking institutions. As its implication, "the gates of traditional banks" forced to change to a new paradigm that emphasizes on the relationship between the banks and their customers, as well as between one company and another company and how the benefits of e-commerce in regional autonomy.
\end{abstract}

Kata Kunci: E-Commerce, Perbankan, Otonomi Daerah

\section{PENDAHULUAN}

Perkembangan ekonomi internasional mengalami perubahan yang cepat dan sangat mendasar menuju kepada sistem ekonomi global yang dit andai dengan semakin terintegrasinya pasar keuangan dunia yang memudahkan pergerakan arus lalu lintas modal disertai dengan semakin ketatnya persaingan di dunia internasional. Selain menguntungkan dalam mendorong pertumbuhan ekonomi, 
perkembangan teknologi elektronik secara khusus juga sangat mempengaruhi dunia perbankan yang juga ikut andil dalam perkembangan sektor ekonomi.

Perkembangan perubahan dalam dunia keuangan pada masa kini merupakan suatu revolusi yang mengajak semua pihak, terutama lembaga perbankan, untuk samasama mengubah paradigma serta cara kerja ke arah yang lebih dinamik dan kompetitif. Landskap kebersaingan dalam ekonomi yang berubah secara dramatis, didorong terutamanya oleh aspek-aspek globalisasi, liberalisasi, ledakan teknologi dan telekomunikasi serta perubahan dalam tingkah laku kepenggunaan.

Tantangan yang lebih besar terpaksa dihadapi oleh lembaga perbankan akibat kebangkitan e-commerce yang merupakan sayap utama e-bisnis ${ }^{1}$ sebagai suatu keadaan perdagangan keuangan antara perusahaan dan masyarakat di seluruh dunia.

Kemajuan teknologi informasi ikut menambah tantangan yang dihadapi oleh perbankan. Perkembangan teknologi informasi (TI) menyebabkan makin pesatnya perkembangan jenis dan kompleksitas produk dan jasa bank sehingga resiko-resiko yang muncul menjadi lebih besar dan bervariasi ${ }^{2}$. Disamping itu, industri perbankan yang cenderung bersifat global juga menyebabkan persaingan antar bank menjadi semakin ketat sehingga bank-bank nasional harus mampu beroperasi secara lebih efisien dengan memanfaatkan teknologi informasi. Salah satu kemajuan dari IT tersebut dengan munculnya arus perkembangan electronic commerce.

Berdasarkan hal itu, pihak perbankan yang berhadapan dan berkaitan dengan perkembangan tersebut perlu melihat arus perubahan itu sebagai suatu tantangan baru untuk mereka mengalihkan gerbang perbankan tradisional kepada strategi dan keadaan yang lebih global dan responsif. Salah satu aspek yang sangat mempengaruhi perkembangan lembaga perbankan di era globalisasi ini adalah dengan munculnya arus perkembangan E-Commerce.

Oleh karena itu, masalah yang akan dibahas dalam artikel ini adalah peluang dan tantangan E-Commerce dalam dunia perbankan. Juga dilihat bagaimana manfaatnya dalam pelaksanaan otonomi daerah yang sedang menuju kepada kesejahteraan masyarakat. Dalam tulisan ini nantinya akan disajikan dan dibahas persoalan lembaga perbankan dalam arus perkembangan e-commerce yang dijabarkan dalam rangkaian permasalahan lembaga perbankan, e-commerce, otonomi daerah, peluang dan tantangan.

\section{PEMBAHASAN}

\section{Lembaga Perbankan}

Pengertian paling luas tentang lembaga adalah sekumpulan aturan atau cara pikir yang baku yang mengatur prilaku individu dalam suatu kelompok masyarakat. Dengan adanya lembaga, maka manusia dapat mengatur kehidupannya menjadi lebih baik dan efisien. Dengan demikian, terkait dengan lembaga keuangan, fokus kita adalah cara pikir yang baku tentang uang dan bagaimana manusia mengalokasikan 
sumber daya keuangan. Dilihat dari sudut pandang ini perkembangan lembaga keuangan merupakan perwujudan dari cara pikir serta pengetahuan tantang uang. Sebuah negara yang memiliki lembaga keuangan yang kuat dan modern berarti telah memiliki perubahan atau kemajuan pola pikir tentang uang dan pengalokasiannya. Hal ini diperlukan untuk menopang perekonomian yang semakin modern.

Secara konsep, pengertian lembaga keuangan (financial institution) adalah lembaga yang kegiatan utamanya mengumpulkan dana dan menyalurkan dana dari pihak yang memiliki kelebihan dana (unit surplus) kepada pihak yang membutuhkan dana (unit deficit). ${ }^{3}$

Pengertian lain dari lembaga keuangan adalah setiap perusahaan yang bergerak dibidang keuangan dimana kegiatannya apakah hanya menghimpun dana atau hanya menyalurkan dana atau kedua-duanya menghimpun dan menyalurkannya. ${ }^{4}$

Sedangkan pengertian bank menurut Undang-Undang nomor 10 Tahun 1998, bank adalah badan usaha yang menghimpun dana dari masyarakat dalam bentuk simpanan dan menyalurkannya ke masyarakat dalam bentuk kredit dan atau bentukbentuk lainnya dalam rangka meningkatkan taraf hidup rakyat banyak.

Secara sederhana, bank diartikan sebagai lembaga keuangan yang kegiatan usahanya adalah menghimpun dana dari masyarakat dan menyalurkan dana tersebut ke masyarakat serta memberikan jasa-jasa bank lainnya. ${ }^{5}$

Di Indonesia, dunia perbankan telah tumbuh dan berkembang seperti jamur di musim hujan. Artinya dunia perbankan di Indonesia memiliki posisi yang sangat potensial dalam menggalang dana dari masyarakat untuk akhirnya digunakan kembali ke dalam masyarakat untuk meningkatkan kesejahteraan sektor perekonomian.

\section{E-Commerce}

E-Commerce pada dasarnya merupakan integrasi diantara teknologi, telekomunikasi dan globalisasi yang bersifat on line dan internet (elektronik) ${ }^{6}$.

Defenisi lain Elektronik Commerce adalah suatu perkembangan dalam mengatur alat-alat teknologi dan teknik penerapannya baik sebagai strategi perusahaan dan mudah dalam pelaksanaannya karena bekerja dengan menggunakan listrik atau elektronik. ${ }^{7}$

Dalam kegiatan elektronik bisnis (e-bisnis), e-commerce merupakan sayap utama yang mendukung kemajuannya. E-commerce membantu mempercepat dan meringkaskan aliran perdagangan tradisional pada bentuk baru dalam aspek pembayaran dan keuangan. Dengan adanya e-commerce bukan saja penggunaan seperti internet banking, on line banking, phone banking, card debit dan kartu kredit yang hanya disediakan, tetapi ia juga membawa pada bentuk e-money atau e-wallet serta kombinasi antara pihak bank, perusahaan asuransi, bursa saham dan broker saham secara maya. ${ }^{8}$ 
Kemajuan praktek perbankan pada zaman ini ditandai dengan beredarnya cek dengan luas sebagai media pembayaran. Bahkan peranan banker telah meliputi tiga aspek, yakni menerima deposit, menyalurkannya dan mentransferkannya. Dalam hal mentransferkan uang, uang dapat ditransfer dari suatu negeri ke negeri lainnya tanpa perlu memindahkan fisik uang tersebut.

\section{Otonomi Daerah}

Otonomi Daerah adalah kewenangan daerah otonom untuk mengatur dan mengurus kepentingan masyarakat menurut prakarsa sendiri berdasarkan aspirasi masyarakat sesuai dengan peraturan perundangan-undangan. ${ }^{9}$

Sedangkan daerah otonomi adalah kesatuan masyarakat hukum yang mempunyai batas daerah tertentu yang berwenang mengatur dan mengurus kepentingan masyarakat setempat menurut prakarsa sendiri berdasarkan aspirasi masyarakat dalam ikatan Negara Kesatuan Republik Indonesia. ${ }^{10}$

Inti konsep pelaksanaan otonomi daerah adalah upaya memaksimalkan hasil yang akan dicapai sekaligus menghindari kerumitan dan hal-hal yang menghambat pelaksanaan otonomi daerah. Dengan demikian, tuntutan masyarakat dapat diwujudkan secara nyata dengan penerapan otonomi daerah luas dan kelangsungan pelayanan umum tidak diabaikan, serta memelihara kesinambungan fiskal secara nasional.

Melalui otonomi daerah diharapkan daerah akan lebih mandiri dalam menentukan seluruh kegiatannya dalam membuka peluang memajukan daerah dengan melakukan identifikasi potensi-potensi sumber daya yang ada secara ekonomi yang wajar, efisien, efektif termasuk dapat menerapkan informasi teknologi agar meningkatkan kinerja kepada pemerintah maupun masyarakat.

\section{Peluang dan Manfaat E-Commerce}

Peranan yang dimainkan oleh Lembaga Perbankan di dalam system ekonomi terdapat dua kelompok atau unit yang utama yaitu; unit surplus dan unit devisi. Unit surplus merupakan bagian yang mempunyai kelebihan uang yang tidak perlu digunakan pada suatu periode. Sedangkan unit devisit bagian yang kekurangan dana dan memerlukannya. Maka disinilah timbulnya lembaga perbankan menjadi orang tengah diantara dua unit tersebut.

Peranan orang tengah yang dimainkan oleh lembaga perbankan telah menciptakan tanggung jawab yang perlu dipenuhi yaitu; meminimalkan pos mendapatkan dana bagi unit devisit, meminimalkan pos mengawasi peminjam bagi unit surplus, menyatukan resiko yang akan dihadapi, menciptakan kelancaran di dalam ekonomi.

Oleh karena itu, berbagai produk yang diciptakan perbankan bagi memenuhi tanggung jawab mereka yang berbentuk online banking dan internet banking dalam e- 
commerce sebenarnya mencoba memenuhi dan memberikan kepuasan kepada masyarakat dan menguntungkan pemegang saham.

Transformasi di dalam sistem perdagangan dan keuangan setelah adanya ecommerce berjalan dengan sangat cepat, pandangan tradisional menyatakan bahwa sistem ekonomi dan perbankan didirikan atas tiga unsur yaitu: modal, tenaga kerja, dan pengusaha. Pada masa kini hal tersebut telah berubah dengan adanya unsur teknologi sebagai faktor tambahan, dimana teknologi memberikan perubahan yang sangat mendalam dalam perkembangan perdagangan dan keuangan. Dengan teknologilah maka kemajuan perekonomian dapat ditingkatkan.

Umumnya terdapat tiga persfektif dalam membicarakan tentang apa yang sedang berlaku dalam perbankan.11 Pertama, perkembangan pesat dalam bidang teknologi komunikasi telah menciptakan berbagai alat serta manfaat baru dalam perdagangan. Sistem computer yang canggih serta peralatan perhubungan yang efektif telah memberikan hal yang baru terhadap dunia perbankan untuk berkembang. Pada masa kini pihak perbankan telah menggunakan internet, online dan telepon. Fokus perbankan juga bertambah dari menjaga kualitas kesigapan dan kesiapan untuk menjaga keperluan dan kehendak pengguna. Kemajuan yang diberikan oleh lembaga perbankan tidak lagi terbatas pada ATM semata, tetapi juga internet banking, online banking dan E-cash. Kedua, globalisasi dan liberalisasi diseluruh dunia mengajak institusi perbankan agar lebih kreatif, berdaya saing, dan cepat bertindak untuk menguasai setiap peluang yang ada. Tujuan globalisasi untuk memperluas dan mendapatkan sebanyak mungkin pemasaran, mewujudkan suasana saling ketergantungan dalam rangkaian perdagangan tertentu, serta mendapatkan kelebihan percepatan ekonomi (economy of speed). Ketiga, mewujudkan knowledge economy (Keconomi) dalam dunia perdagangan yang menekankan pada pentingnya teknologi know how untuk maju. Dalam k-economi, yang diperlukan adalah upaya organisasi mendapatkan sebanyak mungkin maklumat dan pengetahuan dibanding organisasi lain serta diimplementasikan.

Manfaat yang dapat dijelaskan bahwa e-commerce membantu mempercepat dan mempermudah arus perdagangan tradisional pada bentuk baru dalam aspek pembayaran dan keuangan. Dalam dunia perbankan, e-commerce mengurangi biaya transaksi, biaya pindahan dana dan meningkatkan jumlah perdagangan. Ia juga menjadikan proses perdagangan dan pembayaran lebih cepat, produk baru yang lebih inovatif juga tercetus dari pemakaian sistem perdagangan tersebut. Dengan adanya ecommerce bukan saja kemajuan seperti internet banking, online banking, phone banking, card debet dan kredit disediakan tetapi juga mewujudkan e-money serta kombinasi kemajuan antara pihak bank, asuransi dan pemegang saham.

Manfaat lain dari E-Commerce adalah dapat memberi tambahan nilai baik bagi perbankan maupun bagi nasabah, ${ }^{12}$ tambahan nilai tersebut antara lain: mengurangi kos/ biaya yang di keluarkan oleh pihak perbankan, memudahkan proses, baik dari 
kinerja perbankan maupun kemudahan-kemudahan yang diperoleh oleh nasabah, memberikan lebih banyak jasa sehingga dapat memuaskan pihak nasabah perbankan, memudahkan untuk menemukan nasabah-nasabah yang diinginkan oleh pihak Bank dengan adanya teknologi yang bias mendekatkan antara perbankan dan nasabah, mendukung dalam pembuatan keputusan, meningkatkan kegunaan (utility) perbankan sehingga merupakan suatu institusi yang urgen dalam peningkatan perkembangan ekonomi kearah yang lebih maju dengan memberikan bantuan kredit kepada masyarakat dalam menunjang sector perekonomian.

Walaupun e-commerce dapat mengurangi biaya transaksi dan memperkenalkan produk-produk perbankan yang baru yang tidak pernah terpikir oleh kita pada masamasa yang silam. Kecakapan Bank dapat diukur melalui tiga perspektif, yaitu kecakapan operasi, kecakapan tagihan, dan kecakapan keuangan.

Kecakapan operasi dapat dijelaskan bahwa dengan berkembangnya model ecommerce, bank bukan lagi pada keunggaulan bank, tetapi sejauh mana pihak bank dapat memberikan kepuasan dan kemudahan yang dikehendaki oleh konsumen/ pelanggan dan memberikan respon dalam masalah dan permintaan baru mengenai branchless banking. E-commerce juga akan memaksa bank mengurangi jumlah jaringannya. Apabila semakin banyak aktivitas dapat dilaksanakan melalui internet maka tidak perlu lagi pihak bank menyediakan sarana secara berhadapan dengan pelanggan.

Kecakapan keuangan melihat pada upaya bank beroperasi pada biaya yang paling optimal tetapi memberikan hasil yang paling baik. Untuk mencapainya perlu peleburan sistem kemajuan dan teknologi. Walau bagaimanapun, konfik antara ongkos dan keuntungan untuk menggunakan sistem terbaik yang diperlukan oleh e-commerce akan menimbulkan kemudahan. Dibanding bank-bank asing yang lebih maju, bankbank tempatan masih belum sepenuhnya melebur dalam teknologi yang menghabiskan biaya yang cukup tinggi walaupun telah menggunakan sistem elektronik.

Kecakapan tagihan diperlukan agar pihak bank lebih mantap dalam menyampaikan produk-produk mereka kepada pasaran pada biaya yang minimal. Dibandingkan dengan bank asing, mereka lebih cepat menagihkan produk mereka karena telah mempunyai asas sistem tagihan yang sempurna berdasarkan e-commerce. Tagihan berbentuk multiple channel sudah pasti akan lebih cepat.

Dalam rangka otonomi daerah (UU Nomor 22 dan 25 tahun 1999) maka pemerintah dapat mengambil manfaat teknologi informasi dalam pelaksanaan otonomi daerah ${ }^{13}$ sebagaimana table berikut:

Tabel 1

Manfaat Teknologi Informasi dalam Otonomi Daerah

No Manfaat Keterangan




\begin{tabular}{|c|c|c|}
\hline 1 & $\begin{array}{l}\text { Meningkatkan } \\
\text { ketepatan dan } \\
\begin{array}{l}\text { efisiensi, } \\
\text { procepatan } \\
\text { dan bisnis }\end{array}\end{array}$ & $\begin{array}{l}\text { Dengan adanya teknologi informasi } \\
\text { pelaksanaan otonomi daerah dapat } \\
\text { lebih efisien, ketepatan proses } \\
\text { administrasi dapat terlaksana dengan } \\
\text { baik. }\end{array}$ \\
\hline 2 & $\begin{array}{l}\text { Menjadi pendorong adanya } \\
\text { transformasi proses-proses }\end{array}$ & \\
\hline 3 & Melenyapkan isolasi daerah & $\begin{array}{l}\text { Dengan adanya teknologi informasi } \\
\text { maka banyak kemudahan dalam } \\
\text { pelaksanaan otonomi daerah } \\
\text { sehingga jarak bukan merupakan } \\
\text { suatu penghalang didalam } \\
\text { menciptakan kemajuan sehingga } \\
\text { tidak ada isu-isu ketidakadilan di } \\
\text { daerah-daerah. }\end{array}$ \\
\hline 4 & $\begin{array}{l}\text { Perlunya pembinaan sumber } \\
\text { daya manusia }\end{array}$ & $\begin{array}{l}\text { Dengan adanya otonomi daerah } \\
\text { maka kewenangan untuk mengurus } \\
\text { rumah tangga daerah sendiri terlepas } \\
\text { dari pembinaan SDM melalui diklat } \\
\text { dan perubahan budaya kearah yang } \\
\text { lebih maju. }\end{array}$ \\
\hline 5 & $\begin{array}{l}\text { Bila salah dalam perencanaan } \\
\text { dan pelaksanaan maka biaya } \\
\text { yang dikeluarkan akan mahal }\end{array}$ & $\begin{array}{l}\text { Kita ketahui bahwa teknologi } \\
\text { informasi memang mempunyai nilai } \\
\text { yang mahal sekali. Namun demikian } \\
\text { untuk memajukan suatu daerah } \\
\text { tersebut tentu harus diupayakan } \\
\text { agar mendapatkannya meskipun } \\
\text { mengeluarkan biaya yang cukup } \\
\text { banyak. Oleh karena itulah maka } \\
\text { perlunya suatu perencanaan dan } \\
\text { peleksanaan yang baik dan benar } \\
\text { serta transparan agar biaya yang } \\
\text { dikeluarkan sebanding dengan yang } \\
\text { kita harapkan dimana tidak terjadi } \\
\text { pemborosan dana }\end{array}$ \\
\hline
\end{tabular}


Dengan demikian, sumbangan teknologi informasi bagi kelangsungan dan peningkatan ekonomi pada era otonomi daerah tak dapat ditampik lagi.

Sedangkan manfaat E-commerce dalam pelaksanaan otonomi daerah ${ }^{14}$ dapat pula dilihat pada table berikut :

Tabel 2

Manfaat E-Commerce dalam Pelaksanaan Otonomi Dareah

\begin{tabular}{|c|c|c|}
\hline No. & Manfaat & Keterangan \\
\hline 1 & $\begin{array}{l}\text { Pemasaran global dari } \\
\text { produk-produk daerah }\end{array}$ & $\begin{array}{l}\text { Dengan adanya e-commerce maka } \\
\text { banyak kemudahan-kemudahan } \\
\text { yang diperoleh dalam memasarkan } \\
\text { produk-produk daerah, karena } \\
\text { dengan menggunakan e-commerce } \\
\text { maka pemasarannya bukan hanya } \\
\text { bersifat local tetapi dapat } \\
\text { mengglobal menjangkau daerah } \\
\text { yang jauh sekalipun }\end{array}$ \\
\hline 2. & $\begin{array}{l}\text { Mendorong tumbuhnya } \\
\text { entrepreneur daerah yang } \\
\text { kreatif dan inovatif }\end{array}$ & $\begin{array}{l}\text { Sehingga diharapkan dapat } \\
\text { memberikan dan menunjang } \\
\text { otonomi daerah tersebut. }\end{array}$ \\
\hline 3 & $\begin{array}{l}\text { Mempercepat tumbuhnya } \\
\text { Usaha Kecil Menengah } \\
\text { menjadi perusahaan- } \\
\text { perusahaan besar tingkat } \\
\text { nasional dan internasional }\end{array}$ & $\begin{array}{l}\text { E-commerce } \\
\text { kemudahan dalam mengembangkan } \\
\text { UKM menjadi perusahaan- } \\
\text { perusahaan besar, karena manfaat } \\
\text { dari e-commerce tersebut sangat } \\
\text { dirasakan dalam perdagangan } \\
\text { dimana e-commerce berperan } \\
\text { mempermudah dan mengurangi } \\
\text { biaya-biaya transakai, biaya pindah } \\
\text { buku dana dan meningkatkan } \\
\text { jumlah perdagangan. Sehingga e- } \\
\text { commerce baik sekali dalam UKM } \\
\text { menjadi perusahaan yang besar baik } \\
\text { tingkat nasional maupun } \\
\text { internasional }\end{array}$ \\
\hline 4 & $\begin{array}{l}\text { Perlu pengaturan tentang } \\
\text { cukai dan perpajakan }\end{array}$ & $\begin{array}{lll}\text { E-commerce } & \text { dapat dimanfaatkan } \\
\text { oleh pemda } & \text { untuk meningkatkan }\end{array}$ \\
\hline
\end{tabular}




\begin{tabular}{|c|c|c|}
\hline & $\begin{array}{l}\text { disektor e-commerce yang } \\
\text { baik untuk dapat } \\
\text { menjaring } \\
\text { Pendapatan Asli Daerah }\end{array}$ & $\begin{array}{l}\text { PAD, karena dengan adanya } \\
\text { pemakaian e-commerce dalam } \\
\text { perdagangan dan perbankan maka } \\
\text { pemerintah daerah perlu mengatur } \\
\text { tentang cukai dan perpajakannya }\end{array}$ \\
\hline 5. & $\begin{array}{l}\text { Koordinasi dengan pusat } \\
\text { untuk menyusun cyber } \\
\text { law, UU perpajakan dll }\end{array}$ & $\begin{array}{l}\text { Dengan adanya e-commerce maka } \\
\text { daerah dapat berkoordinasi dengan } \\
\text { pusat dalam penyusunan cyber law } \\
\text { dan UU perpajakan sehingga daerah } \\
\text { juga dapat memberikan masukan- } \\
\text { masukan kepada pihak pusat dalam } \\
\text { mengambil kebijakan. }\end{array}$ \\
\hline 6. & $\begin{array}{l}\text { Penerapan } r \text { teknologi } \\
\text { informasi yang tepat guna } \\
\text { dapat menyelesaikan } \\
\text { berbagai masalah yang } \\
\text { timbul. }\end{array}$ & $\begin{array}{l}\text { Dengan adanya teknologi informasi } \\
\text { maka dapat memberikan alternative } \\
\text { dalam penyelesaian masalah yang } \\
\text { kita hadapi. Sehingga penerapan } \\
\text { teknologi informasi yang tepat } \\
\text { sangat membantu dalam } \\
\text { pelaksanaan otonomi daerah }\end{array}$ \\
\hline
\end{tabular}

\section{Manfaat bagi Perempuan}

Bagi kaum perempuan, manfaat dari e-commerce adalah mempermudah kaum perempuan dalam mengakses informasi dari perbankan. Kaum perempuan yang notabennya adalah ibu rumah tangga membutuhkan waktu seharian penuh dalam melaksanakan kesibukan dan rutinitas di dalam rumah tangga, sehingga waktu yang digunakan untuk urusan keuangan yang juga cukup menyita waktu akan menambah berat tugas perempuan dalam membagi waktu antara di dalam rumah dengan di luar rumah. Oleh karena itu, urusan yang terkait dengan perbankan dan banyak diserahkan kepada para pria atau bapak sebagai kepala rumah tangga.

Dengan adanya e-commerce di dunia perbankan maka kaum perempuan dapat mengambil manfaat dari penerapan e-commerce ini di tengah-tengah kesibukannya di rumah tangga. Fasilitas yang dapat digunakan adalah phone-banking, sms-banking dan internet-banking yang disediakan oleh pihak perbankan. Dengan demikian, para ibuibu rumah tangga dapat menghemat waktu dan tenaganya dengan bertransaksi di rumah saja tanpa pergi ke bank. Para ibu rumah tangga juga dapat melakukan transaksi-transaksi seperti pengecekan saldo tabungan, pembayaran tagihan telephon, tagihan listrik, pembayaran kartu telepon dan pembelian voucher, pembayaran tiket pesawat, dan transaksi bisnis lainnya. 
Selain manfaat di atas, e-commerce juga memberikan kemudahan dan keamanan dalam melakukan transaksi lain, yaitu dengan card debet dan kredit yang dimiliki kaum perempuan, maka dalam melakukan transaksi perdagangan mereka tidak perlu membawa uang kontan yang banyak, cukup dengan card debet dan kredit saja akan mendapatkan kemudahan dalam bertransaksi. Hal demikian cukup memberikan rasa aman bagi kaum perempuan dalam membelanjakan uang mereka. Karena kaum perempuan pada umumnya rentan terkena penipuan, copet, jambret, dan sebagainya. Dengan alasan demikian pula, kaum perempuan tidak perlu lagi menunggu waktu luang bersama suami untuk menemani berbelanja kebutuhan sehari-hari.

Dengan demikian, dapat disimpulkan bahwa e-commerce memberikan kemudahan bagi kaum perempuan pada umumnya, dan khususnya para ibu rumah tangga dalam melakukan transaksi dengan pihak perbankan, pertama hemat waktu dan tenaga, kedua hemat biaya dan efisien, ketiga terciptanya rasa aman baik dari segi finansial maupun keselamatan diri.

\section{Tantangan E-Commerce}

Bagaimanapun, lembaga keuangan tanpa terkecuali perbankan yang sudah maju dengan produk-produk yang dianggap efektif dan efisien bagi perbankan sendiri maupun bagi para nasabahnya, mempunyai tantangan untuk kemajuan dan kelancaran programnya. Tantangan dari e-commerce adalah berkaitan dengan kelancaran dalam institusi perbankan. Kelancaran merupakan aspek terpenting dalam menjalankan urusan perdagangan. Dengan adanya e-commerce tentu akan mempermudah konsumen dalam melakukan transaksi perdagangan pada setiap waktu. Keadaan ini mengakibatkan Bank harus lebih hati-hati dalam mengurus asset dan liabilitynya.

Tantangan lain adalah bagaimana menarik dan mengekalkan pelanggan atau konsumen yang sudah ada dan yang baru. Konsumen masa kini mempunyai kuasa tawar menawar yang kuat karena mereka mendapatkan kemudahan-kemudahan yang sama di bank-bank lain dengan adanya e-commerce.

Tantangan lain yang perlu dipikirkan adalah berkaitan dengan produk. Produk perbankan di bawah e-commerce akan membawa institusi ini lebih berorientasi pada konsumen atau nasabah. Ini disebabkan penawaran produk yang terbanyak adalah produk bersifat "lifestyle product" seperti kartu kredit dan online banking.

Tantangan-tantangan tersebut tidak dapat diselesaikan hanya oleh lembaga perbankan tetapi pemerintah perlu mengambil kebijaksanaan- kebijaksaan agar pihak perbankan dan konsumen atau nasabah dapat sama-sama memberikan kepuasan yang hendak dicapai.

E-commerce di Indonesia sudah mulai berkembang dan diterapkan dalam pelaksanaan Otonomi Daerah. Namun demikian masih menghadapi kendala dalam pengoperasian teknologi ini, dikarenakan masih rendahnya kualitas Sumber Daya Manusia (SDM) yang dapat mengerti dan menggunakan E-commerce. Kendala lain 
yang masih ada antara lain di bidang keamanan, budaya, infrastruktur IT, dan infrastruktur hukum, karna sampai saat ini belum ada aturan hukum berupa Perda yang mengatur e-commerce ini.

\section{SIMPULAN}

E-commerce memang memberikan banyak imbas dan tantangan terhadap perdagangan dan perbankan masa kini. Walau bagaimanapun ini akan dapat diatasi bila mereka cepat mengambil peluang dan mematahkan ancaman yang ada. Diantara yang perlu dilakukan adalah dengan melihat awal kedudukan saingan, membentuk hubungan yang menambah nilai dengan konsumen serta memanfaatkan e-commerce sebagai salah satu saluran tagihan yang penting.

E-commerce akan menjadi komoditi dalam pasaran pada suatu masa nanti. Oleh karena itu lembaga perbankan perlu memperoleh nilai tambah dalam hubungan antara konsumen atau nasabah perbankan. Sedangkan dalam otonomi daerah e-commerce merupakan sarana yang tepat untuk meningkatkan ekonomi daerah. pemerinah dan ekonomi rakyat. E-commerce dapat mempercepat pertumbuhan ekonomi dan perdaganga sampai ke daerah-daerah agar pemerataan pembangunan tercapai, dan pada sektor kelembagaan pemerintah kiranya dapat melayani masyarakat dengan lebih cepat dan efisien. Untuk itu pemerintah Riau baik di semua sektor harus memelopori dan memfasilitasi penyediaan prasarana informasi teknologi untuk e-commerce. Meskipun E-commerce sudah berkembang namun masih menghadapi kendala di bidang keamanan, budaya dan infrastruktur hukum.

\section{Endnotes :}

1 Faisal Mustaffa,"Institusi Perbankan dalam Arus Perkembangan E-Commerce", Oktober 2000

2 "Bank Fail Small Bisniess on the Web", Financial Technology Buletin, Juni 2000

3 Mandala Manurung," Uang, Perbankan dan Ekonomi Moneter", FEUI, 2004

4 Ibid.

5 Shanmungam, "Big on Banking on the Net", Malaysia Bisnis, 1 May 2000

6 Ashworth, "E-Commerce Banking", 1999

7 Siegel, 2000

8 Hazamuddin Awang," Perbankan Generasi Internet dalam Ekonomi Digital", Juni 2000

9 Undang-Undang No. 22 Tahun1999 tentang Pemerintah Daerah

${ }^{10}$ Widjaja," Otonomi Daerah dan Daerah Otonomi", Rajawali Pres,2001

11 Ade Dian Hardiana, "Penerapan E-Commerce di Indonesia", Oktober 2000

${ }^{12}$ Balino \& Ubide,"The New World of Banking", Finance and Development, Juni 2000

${ }_{13}$ Kuncoro, Mudrajad, Otonomi dan Pembangunan Daerah, Erlanga,2004

14 Reostam , Ir. Sumitro,"Penerapan Teknologi Informasi dan E-Commerce Menyongsong Otonomi Daerah dan Era Globalisasi, Bandung, Agustus 2000 


\section{DAFTAR PUSTAKA}

Ade Dian Hardiana, “Penerapan E-Commerce di Indonesia”, Oktober 2000.

Ashworth, “E-Commerce Banking”, 1999

Balino \& Ubide,"The New World of Banking", Finance and Development, Juni 2000

"Bank Fail Small Bisniess on the Web", Financial Technology Buletin, Juni 2000

Faisal Mustaffa," Institusi Perbankan dalam Arus Perkembangan E-Commerce", Oktober 2000

Hazamuddin Awang, "Perbankan Generasi Internet dalam Ekonomi Digital", Juni 2000

Kuncoro, Mudrajad, Otonomi dan Pembangunan Daerah, Erlangga, 2004

Mandala Manurung, Uang, Perbankan dan Ekonomi Moneter, FEUI, 2004

Reostam, Ir. Sumitro,"Penerapan Teknologi Informasi dan E-Commerce Menyongsong Otonomi Daerah dan Era Globalisasi," Bandung, Agustus 2000

Shanmungam, "Big on Banking on the Net", Malaysia Bisnis, 1 May 2000

Siegel, 2000

Undang-Undang No. 22 Tahun1999 tentang Pemerintah Daerah

Undang-Undang No. 25 Tahun 1999 tentang Perimbangan Keuangan

Widjaja, Otonomi Daerah dan Daerah Otonomi, Rajawali Pres, 2001 